\title{
Приходько В.П.,
}

доктор економічних наук, професор,

завідувач кафедри міжнародних економічних відносин, директор НДI

«Інститут державного управління та регіонального розвитку»

Ужггородського начіонального університету

(м. Ужггород, Украӥна)

\section{ВЗАСМОДІЯ УНІВЕРСИТЕТІВ І КОРПОРАЩЙ: ПІДТРИМКА ІНВЕСТИЦЙ У СИСТЕМУ ВИЩОЇ ОСВІТИ ТА ТРЕНІНГУ ПЕРСОНАЛУ В ТРАНСКОРДОННИХ РЕГІОНАХ УКРАЇНИ ТА КРАЇ̈ ЄС}

Якість бізнес-освіти та підготовки персоналу корпоративного управління відчутно стримуе ефективну імплементацію Угоди про асоціацію та всеосяжну зону вільної торгівлі між Украйною та СС, ухвалення адекватних рішень у сфері зовнішньоекономічної політики. Зростає актуальність інновачійних інструментів докорінного перезавантаження менеджменту $i$ персоналу, $\ddot{i x}$ переоріснтації на європейські форми, методи та технології публічного та бізнесадміністрування, їх організачуійні та моральні засади.

Ключові слова: інноваційний університет, бізнес-освіта, корпоративне управління, міжнародна фінансова допомога, міжнародний консориіум, Європейський інвестиційний банк.

Business education and corporate governance staff training quality significantly impedes the effective implementation of the Ukraine - EU Association Agreement and the comprehensive free trade, adopting adequate decisions in the field of foreign economic policy. The urgency of innovative tools of radical reloading of management and personnel, their reorientation to European forms, methods and technologies of public and business administration, their organizational and moral principles is increasing.

Key words: innovation university, business education, corporate governance, international financial assistance, international consortium, European investment bank.

Постановка проблеми. Збереження та якісне посилення ролі вищого навчального закладу - інтегратора освітньо-наукового та інноваційного середовища і регіонального розвитку Закарпатського регіону є ефективним та важливим напрямом економіко-освітньої трансформації Ужгородського національного університету, адекватною відповіддю на виклики часу.

Висока ймовірність того, що в терміни реалізації Концепції інноваційного розвитку ДВНЗ “Ужгородський національний університет” на 2015-2025 рр. стрімкий розвиток ІТ-технологій, шляхів сполучень та логістики, візова лібералізація об єктивно посилять проникнення і вплив на розвиток освітньо-інноваційного середовища області технічно-орієнтованих 
вищих навчальних закладів таких категорій високої регіональної та міжнародної впливовості, як “університети й інститути провідних економічних регіонів" нашої країни (Львівський та Київський регіони) та традиційно близьких до регіону i партнерських 3 УжНУ освітньоінноваційних агломерацій (Кошицько-Пряшівської, Будапештської, Братиславської, Віденської, Празької, Краківської та Варшавської) країнчленів ЄС / Вишеградської групи [1].

Вбачаються прояви конкурентної боротьби за освітній контингент у середовищі національних громад, на площинах логістичних та вартісних переваг, можливостей міжнародної мобільності, отримання i визнання європейського диплома [ 2, с. 43-65 ].

Зазначене створює для вищих навчальних закладів цієї групи регіональної впливовості, у тому числі УжНУ, менш когерентну систему. Освітньо-інноваційне середовище регіону відстає від загальнодержавних і європейських параметрів охоплення населення вищою освітою, доступом до якісної бізнес-освіти та сучасних тренінгових послуг.

Водночас і у сфері життєдіяльності українських бізнесу та корпорацій якість освіти та підготовки персоналу, зокрема державного та корпоративного управління, відчутно стримує результативний європейський транзит, досягнення параметрів сталого розвитку, переходу до вищих економічних укладів та ухвалення продуктивних рішень 3 питань зовнішньоекономічної політики [3].

Аналіз останніх досліджень та публікацій. У роботах вітчизняних та зарубіжних дослідників А. Чухна, А. Гальчинського, В. Кременя, В. Лугового, І. Каленюка, О. Куклінова, І.В. Артьомова, І.П. Студеняка, Д. Строгілопулоса, Г. Румпф, Л. Чабійової, Я. Черної та ін. задано напрям актуальних на сучасному етапі досліджень, присвячених перетворенню закладів вищої школи в ефективний фактор інтеграції до європейського освітньо-інноваційного та наукового простору заради втілення європейських стандартів та пропозиції світовій та національним економікам своїх напрацювань і досягнень [4].

Виділення невирішених раніше частин загальної проблеми. Недостатньо розробленими залишаються такі проблеми, як пріоритетне значення вищих навчальних закладів в якості рушійних факторів інноваційного розвитку регіональної економіки, формування регіональних інтеграційних пріоритетів розвитку вищої освіти відповідно до вимог економіки знань, вдосконалення механізму реалізації економічної функції вищої освіти в умовах реального сектору регіональної економіки, вплив транскордонної співпраці регіонів держави та країн СС на трансформацію механізму функціонування вищих начальних закладів - лідерів регіону своєї локалізації.

Мета дослідження - вивчити та запропонувати шляхи створення інноваційної освітньої платформи публічного та бізнес-адміністрування для нового покоління підприємців, персоналу державних інституцій i приватного сектору, представників провідних національних громад України 
та регіону, інтелектуальні та організаційно-структурні можливості та інвестиційні складові у вигляді взаємодії університету - регіонального інтегратора 3 корпораціями та підприємницькими колами та допомоги міжнародних фінансових організацій.

Виклад основного матеріалу дослідження. Результати проведеного аналізу шляхів створення та функціонування на ринках освітніх послуг та праці інноваційної освітньої платформи у сфері бізнес- адміністрування та складові проектної розробки відображено в таблиці 1. На їі “полях" ми і прокоментуємо лише принципові питання.

Таблиця 1

\section{Результати аналізу шляхів створення та функціонування на ринках освітніх послуг та праці інноваційної освітньої платформи у сфері бізнес-адміністрування та складові проектної розробки}

\begin{tabular}{|c|c|}
\hline Засновники (учасники) & $\begin{array}{l}\text { Міжнародний консорціум у складі вищих навчальних } \\
\text { закладів (зокрема Карлів університет м. Прага (ЧР), } \\
\text { Університет м. Жешув (РП), Технічний університет м. } \\
\text { Кошице (СР), Університет . Дебрецен (Угорщина) } \\
\text { та ін. }\end{array}$ \\
\hline Назва проекту & $\begin{array}{l}\text { Утворення } \\
\text { міжнародного Центру (Інституту) } \\
\text { підготовки та перепідготовки } \text { менеджменту і } \\
\text { персоналу УжНУ } 3 \text { метою ї переорієнтації на } \\
\text { європейські форми, методи та технології публічного } \\
\text { та бізнес-адміністрування. }\end{array}$ \\
\hline $\begin{array}{l}\text { Опис запропонованого } \\
\text { інвестиційного проекту (наприклад, } \\
\text { процеси, технології, які будуть } \\
\text { використовуватися) }\end{array}$ & $\begin{array}{l}\text { Вид діяльності. Інноваційна та освітня економіка, } \\
\text { публічне та бізнес-адміністрування. Підготовка і } \\
\text { перепідготовка сертифікованих спеціалістів. }\end{array}$ \\
\hline $\begin{array}{l}\text { Ключові параметри необхідного } \\
\text { обладнання }\end{array}$ & $\begin{array}{l}\text { Мультимедійні комплекси. Меблі } \\
\text { аудиторій та офісні меблі. Компюютери та засоби } \\
\text { зв язку. Витратні офісні матеріали. Видавниче } \\
\text { обладнання. Транспортні засоби. }\end{array}$ \\
\hline $\begin{array}{l}\text { Охоплення проекту (наприклад, } \\
\text { територія/кількість населення, що } \\
\text { обслуговується) }\end{array}$ & $\begin{array}{l}\text { Транскордонні регіони Австрії, Чехії, України, } \\
\text { Польщі, Словаччини, Угорщини, Румунії. }\end{array}$ \\
\hline $\begin{array}{l}\text { Ключові зацікавлені сторони } \\
\text { (наприклад, муніципалітет) та їхня } \\
\text { роль в інвестиційному проекті }\end{array}$ & $\begin{array}{l}\text { Державне і корпоративне замовлення на підготовку і } \\
\text { перепідготовку спеціалістів. Державно-приватне } \\
\text { партнерство. Органи державної виконавчої влади та } \\
\text { місцевого самоврядування транскордонних регіонів , } \\
\text { міжнародні та неурядові } \\
\text { установи,економічні анганізації і } \\
\text { Австрії, України, Польщі, Словаччини, Угорщини, } \\
\text { Чехії, Румунії. }\end{array}$ \\
\hline $\begin{array}{l}\text { Вихідні дані: } \\
\text { Охоплені проектом - вхідні } \\
\text { ресурси для інвестиційного проекту }\end{array}$ & $\begin{array}{l}\text { Персонал органів державної виконавчої влади та } \\
\text { місцевого самоврядування транскордонних регіонів, } \\
\text { міжнародних та неурядових організацій і установ, } \\
\text { економічних анклавів та підприємств Австрії. } \\
\text { України, Польщі, Словаччини, Угорщини, Чехії, } \\
\text { Румунії, інших країн. }\end{array}$ \\
\hline
\end{tabular}




\begin{tabular}{|c|c|}
\hline $\begin{array}{l}\text { Існуюча система діяльності } \\
\text { охопленої проектом }\end{array}$ & 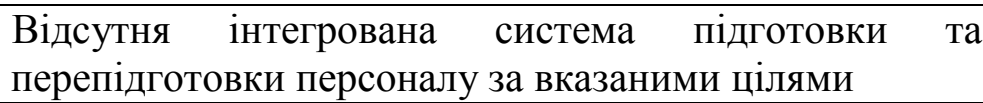 \\
\hline Кінцевий результат & $\begin{array}{l}\text { Підготовка і перепідготовка сертифікованих } \\
\text { спеціалістів у галузях: } \\
\text { - регіональна економіка, кластерний і сталий } \\
\text { розвиток територій; } \\
\text { - інвестиційний менеджмент; } \\
\text { - імплементація Угоди про асоціацію між Україною } \\
\text { та ЄС; } \\
\text {-проектний менеджмент, підготовка та реалізація } \\
\text { проектів співробітництва за програмами Східного } \\
\text { партнерства, Карпатського єврорегіону, ЕGTС, } \\
\text { міжрегіональної співпраці; } \\
\text { - зовнішньоекономічна діяльність } \\
\text { у співпраці з відповідними інституціями та агенціями } \\
\text { країн СС та Вишеградської групи. }\end{array}$ \\
\hline $\begin{array}{l}\text { Ринок продукції (тобто які об’єкти } \\
\text { в Україні будуть використовувати } \\
\text { отриману продукцію) }\end{array}$ & $\begin{array}{l}\text { Органи державної виконавчої влади та місцевого } \\
\text { самоврядування } \\
\text { міжнародні та неурядові організації і установи, } \\
\text { економічні анклави та підприємства Австрії України, } \\
\text { Польщі, Словаччини, Угорщини, Чехії, Румунії та ін. }\end{array}$ \\
\hline $\begin{array}{l}\text { Загальна кількість осіб, } \\
\text { безпосередньо зайнятих, коли } \\
\text { проект буде розпочато }\end{array}$ & До 20 чол. \\
\hline $\begin{array}{l}\text { Резюме екологічної і соціальної } \\
\text { вигоди від проекту }\end{array}$ & $\begin{array}{l}\text { Позитивні. Переорієнтація українського державного } \\
\text { та корпоративного персоналу на європейські форм, } \\
\text { методи і технології публічного та бізнес - } \\
\text { адміністрування, їх організаційні та моральні засади. } \\
\text { Засвоєння принципів сталого розвитку територій } \\
\text { інноваційної та зеленої економіки. }\end{array}$ \\
\hline \multicolumn{2}{|l|}{ Фінансовий та економічний аналіз } \\
\hline Капітальні витрати (CAPEX) & Уточнюються відповідно до контингенту \\
\hline $\begin{array}{l}\text { Щорічні операційні витрати } \\
\text { (OPEX) }\end{array}$ & Уточнюються відповідно до контингенту \\
\hline $\begin{array}{l}\text { Інші витрати (наприклад, витрати } \\
\text { на реконструкцію і } \\
\text { післяексплуатаційні витрати } \\
\text { наприкінці життєвого циклу } \\
\text { проекту) }\end{array}$ & Уточнюються відповідно до контингенту \\
\hline $\begin{array}{l}\text { Джерела фінансування проекту і } \\
\text { обсяг бажаного кредиту від СБРР }\end{array}$ & $\begin{array}{l}\text { Комплекс навчальних, наукових, видавничих та } \\
\text { інфраструктурних заходів потребуватиме } 3 \text { млн. євро. }\end{array}$ \\
\hline $\begin{array}{l}\text { Джерела доходів і аспекти } \\
\text { окупності }\end{array}$ & $\begin{array}{l}\text { Міжнародна фінансова та технічна допомога. } \\
\text { Державно-приватне партнерство. Плата за } \\
\text { навчання,консалтингові та сертифіковані тренінгові } \\
\text { послуги, організацію івентів у галузі наукового та } \\
\text { конгрес-туризму. }\end{array}$ \\
\hline \multicolumn{2}{|l|}{ Аспекти реалізації проекту } \\
\hline $\begin{array}{l}\text { Поточний стан проекту (наприклад, } \\
\text { підготовлений бізнес-план, } \\
\text { розроблено проектну } \\
\text { документацію, отримано } \\
\text { погодження та дозволи і т.д.) }\end{array}$ & $\begin{array}{l}\text { Підготовлено проектну пропозицію,розроблено } \\
\text { робочі плани і програми навчання, тренінгів, } \\
\text { досягнуто взаєморозуміння партнерів. У організації } \\
\text { навчального процесу, додатковому навчально- } \\
\text { методичному забезпеченні, забезпеченні запрошеної }\end{array}$ \\
\hline
\end{tabular}




\begin{tabular}{|c|c|}
\hline & 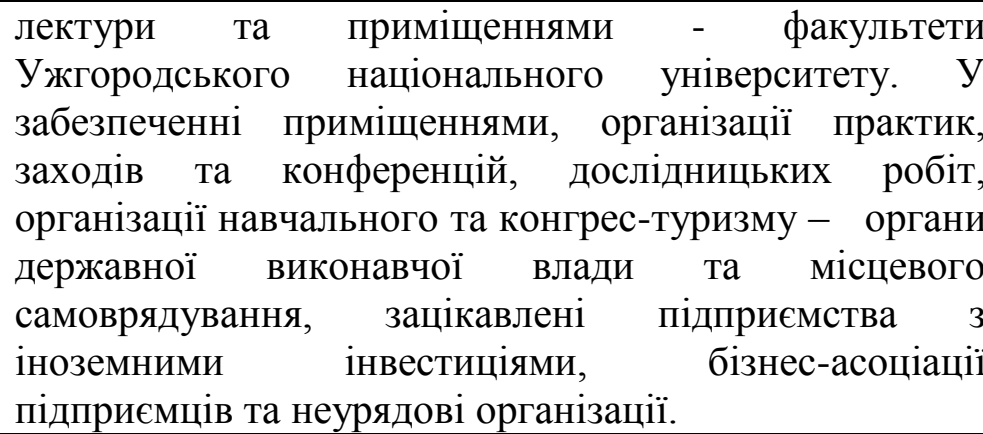 \\
\hline $\begin{array}{l}\text { Яким чином будуть проводитись } \\
\text { закупівлі/реалізація проекту (тобто } \\
\text { проект в цілому або } \\
\text { фази/компоненти проекту) }\end{array}$ & $\begin{array}{l}\text { Дотримання принципів, викладених у директивах СС } \\
\text { про закупівлі } 3 \text { необхідними процедурними } \\
\text { поправками національного законодавства. }\end{array}$ \\
\hline $\begin{array}{l}\text { Календарний план-графік реалізації } \\
\text { проекту }\end{array}$ & Уточнюється - 3 роки. \\
\hline $\begin{array}{l}\text { Основні ризики, пов’язані з } \\
\text { проектом (наприклад, зміни в } \\
\text { законодавстві, зміни в } \\
\text { оподаткуванні, нестабільність в } \\
\text { органах державної влади, валютні } \\
\text { ризики, юридичні та договірні } \\
\text { ризики, страхові ризики, } \\
\text { технологічні ризики, ризики попиту } \\
\text { (тобто стосовно аспектів вхідних } \\
\text { та отриманих даних } \\
\text { продукції/ресурсів, відсутність } \\
\text { підходящих кадрів, форс-мажорні } \\
\text { ризики і т.д. ) }\end{array}$ & $\begin{array}{l}\text { Існують (у рамках процесів реформування України та } \\
\text { СС) }\end{array}$ \\
\hline \multicolumn{2}{|l|}{ Законодавчі вимоги } \\
\hline $\begin{array}{l}\text { Відомості про } \\
\text { законодавчі/нормативні вимоги по } \\
\text { проекту }\end{array}$ & $\begin{array}{l}\text { Стратегія залучення, використання та моніторингу } \\
\text { міжнародної технічної допомоги і співробітництва } 3 \\
\text { міжнародними фінансовими організаціями на 2013- } \\
2016 \text { рр. } \\
\text { Законодавство про освіту. } \\
\text { Відповідні міжнародні угоди вищих навчальних } \\
\text { закладів. }\end{array}$ \\
\hline Отримані дозволи & $\begin{array}{l}\text { Діючі статути вищих навчальних та науково- } \\
\text { дослідних закладів }\end{array}$ \\
\hline $\begin{array}{l}\text { Подальші дозволи, необхідні для } \\
\text { проекту }\end{array}$ & $\begin{array}{l}\text { Угоди між Європейським інвестиційним банком та } \\
\text { вищими навчальними закладами - партнерами. }\end{array}$ \\
\hline
\end{tabular}

Вважасмо, що осередком та безпосередньою ціллю проекту взасмодії університетів та корпорацій може стати створення та функціонування відповідного міжнародного навчального центру - міжнародного Карпатського центру (інституту) професійного управління (бізнесу) зі спеціалізаціями підготовки та перепідготовки спеціалістів сталого розвитку, «зеленої економіки», транскордонної співпраці, зовнішньоекономічних 
зв’язків та стимулювання інноваційно-інвестиційної діяльності, організації наукового та конгрес-туризму у цих напрямах (Карпатський Давос).

Аналіз попередніх досвідів і практик. Ужгородський національний університет, його інженерно-технічний, математичний, фізичний факультети, факультет міжнародних економічних відносин, НДІ “Інститут державного управління та регіонального розвитку” має досвід партнерства 3 International School of Management (Frankfurt), Київським національним транспортним університетом України, українськими підприємствами корпорацій «Ядзакі», «Джейбіл», “Флекстронікс”, ТОВ “Вищий навчальний заклад "Інститут євробізнесу”, що належить провідному виробнику автомобілів «Шкода» в Україні - ПАТ “Єврокар”, програм MBA и LLM 3 наданням сертифіката міжнародного зразка, у сфері підготовки інженерів 3 MBA і володінням іноземними мовами, рекрутингу персоналу, в т. ч. підбору i тренінгу середньої ланки менеджменту. Синергетичний ефект справлятимуть на діяльність інституції практики партнерських вишів членів Міжнародного консорціуму університетів.

Виконавець проекту. Носієм та реципієнтом програми фінансування міг би стати новостворений міжнародний Центр (інститут) бізнесу, підготовки та перепідготовки менеджменту i персоналу УжНУ , забезпечений відповідним персоналом та офіційною державною реєстрацією, i, що важливо у цьому випадку, прозорою кредитною історією. До роботи в установі залучатимуться представники різних факультетів, партнерських вишів міжнародного консорціуму та представники різних національних громад регіону.

Партнери. В організації навчального процесу, додатковому навчальнометодичному забезпеченні, запрошенні вітчизняної та зарубіжної лектури та наданні приміщень - відповідні факультети Ужгородського національного університету та вишів - партнерів. У забезпеченні приміщеннями, організації практик, заходів та конференцій, дослідницьких робіт, навчального та конгрес-туризму - зацікавлені партнерські підприємства вітчизняних власників та з іноземними інвестиціями, у тому числі вищезгадані.

Форми i методи, технології та інструменти. Підготовка i перепідготовка сертифікованих спеціалістів у галузях:

- регіональна економіка і сталий розвиток територій;

- інвестиційний менеджмент та аутсорсинг;

- $\quad$ кластерний розвиток, зокрема у сфері туризму і рекреації, освіти та регіонального трансферту технологій; водо- і лісокористування;

проектний менеджмент, підготовка та реалізація проектів співробітництва за програмами Східного партнерства, Карпатського єврорегіону, ЕGTC, міжрегіональної співпраці;

зовнішньоекономічна діяльність, імплементація Угоди про асоціацію та зону вільної торгівлі між Україною та СС;

у співпраці з відповідними інституціями та агенціями країн США, ЄC, Японії та Вишеградської групи. 
Фінансовим механізмом забезпечення функціонування вищеназваного центру може стати утворення Фонду мікрокредитування інвестицій у систему вищої освіти та тренінгу персоналу в транскордонних регіонах України та країн СС відповідно до існуючої практики СІБ [5].

Рамковою угодою між Україною та Банком (надалі ЄІБ) від 12.02.2005 (ратифікованою Законом України № 3392 від 7.02.2006 р.), Декларацією між МОН України та СІБ) від 12.03.2013 р. про наміри стосовно співробітництва у сфері фінансування проектів у галузі вищої освіти, Меморандумом взаєморозуміння між Україною та СІБ (С. Кубів - В. Гудак, за участі єврокомісара М. Шевчовіча) передбачено інтенсифікацію співпраці, реалізацію у 2017-2020 рр. проектів у таких галузях як транспорт, енергетика, енергозбереження, муніципальний розвиток, освіта та інновації. Зокрема на підвищення енергоефективності та придбання обладнання для українських вишів окремою фінансовою угодою у рамках проекту СІБ “Вища освіта України. Енергоефективність та сталий розвиток” від 19.12.2016 р. передбачено виділення кредиту у 30 млн. євро. [6].

Вищеназвана державно-корпоративна навчальна установа могла б самотужки або в партнерстві 3 зацікавленою структурою в $Є С$, у відповідності до методики роботи ЄІБ в Україні, стати реципієнтом фінансового проекту СІБ чи уповноважених банків України в рамках програм підтримки приватного бізнесу, енергоефективності та сталого i муніципального розвитку [7].

Висновки та вироблення практичних рекомендацій. В умовах Карпатського єврорегіону та унікального за історією,досвідом євроінтеграції та потенціалом прикордоння країн Вишеградської групи та України відповіддю на суспільний та економічний попит може стати створення платформи публічного та бізнес - адміністрування для нового покоління підприємців, персоналу державних інституцій i приватного сектору, представників провідних національних громад України та регіону у вигляді відповідного кадрового центру (інституту) професійного управління 3 спеціалізаціями підготовки та перепідготовки спеціалістів сталого розвитку, «зеленої економіки», транскордонної співпраці, зовнішньоекономічних зв’язків та стимулювання інноваційно-інвестиційної діяльності, організації наукового та конгрес-туризму у цих напрямах (Карпатський Давос). Інтелектуальною та організаційно-структурною площиною його створення могли б стати можливості університету - регіонального інтегратора та його 3 міжнародного консорціуму, інвестиційно-ресурсною складовою корпоративні інвестиції та допомога міжнародних фінансових організацій.

Фінансовим механізмом забезпечення функціонування вищеназваного центру може стати утворення Фонду мікрокредитування інвестицій у систему вищої освіти та тренінгу персоналу в транскордонних регіонах України та країн СС відповідно до існуючої практики СІБ. 


\section{СПИСОК ВИКОРИСТАНИХ ДЖЕРЕЛ}

1. Концепція інноваційного розвитку ДВНЗ "Ужгородський національний університет" на 2015-2025 рр. - Ужгород: ДВНЗ “УжНУ”, ННІЄД, 2016 - 72 c.

2. Розвиток транскордонного співробітництва: науково-аналітична доповідь / ДУ "Інститут регіональних досліджень імені М. І. Долішнього НАН України"; наук. ред. В.С. Кравців. - Львів, 2016. - 125 с. (Серія “Проблеми регіонального розвитку”) [Електронний ресурс]. - Режим доступу : http://ird.gov.ua/irdp/p20160401.pdf

3. Економіка Європейского Союзу [Електронний ресурс]. - Режим доступу: http://ec.europa.eu/eurostat/ Президенти України i країн Вишеградської четвірки домовилися про новий формат співпраці [Електронний ресурс]. - Режим доступу:http://ukr.segodnya.ua/politics/pnews/ prezidenty-ukrainy-i-stran-/Форсайт економіки України: середньостроковий (2015-2020 роки) і довгостроковий $(2020$ - 2030 роки) часові горизонти / наук. керівник проекту акад. НАН України М. З. Згуровський / Міжнародна рада $з$ науки (ICSU) та ін. - К.: НТУУ “КПІ”, 2015. - 136 с.

4. Інноваційний університет: концепція становлення i розвитку: монографія / І.В. Артьомов, І.П. Студеняк, С.І.Устич та ін..; за загальною редакцією І.В.Артьомова. - Ужгород: ДВНЗ “УжНУ”, 2016. - 524 с. [Серія “Свроінтеграція : український вимір”. Вип.30 ].

5. Вдовенко Ю. Україна та Європейський інвестиційний фонд Еберта. Українська призма. Співпраця України 3 міжнародними організаціями . [Електронний ресурс]. - Режим доступу: http://www.fes.kiev.ua/new/wb/media/ publikationen/prizma_ukr_int_2014.pdf. p. 16-25

6. Міністерство економічного розвитку та торгівлі України [Електронний ресурc]. - Режим доступу: www.me.gov.ua/

7. Міністерство закордонних справ України [Електронний ресурс]. Режим доступу: www.mfa.gov.ua/

\section{REFERENCES}

1. Kontseptsiya innovatsiynoho rozvytku DVNZ "Uzhhorods'kyy natsional'nyy universytet" na 2015-2025 rr. (2016) [The concept of innovative development for SU "Uzhhorod National University" at 2015-2025]. Uzhhorod, 72.

2. Rozvytok transkordonnoho spivrobitnytstva (2016) [Development of cross-border cooperation]. naukovo-analitychna dopovid' / DU "Instytut rehional'nykh doslidzhen' imeni M. I. Dolishn'oho NAN Ukrayiny"; nauk. red. V.S. Kravtsiv. - L'viv, 125. Retrieved from: http://ird.gov.ua/irdp/p20160401.pdf

3. Ekonomika Yevropeyskoho Soyuzu [The economy of the European Union]. Retrieved from: http://ec.europa.eu/eurostat/ Prezydenty Ukrayiny i krayin Vyshehrads'koyi chetvirky domovylysya pro novyy format spivpratsi [Presidents of Ukraine and the Visegrad countries agreed on a new format for cooperation]. Retrieved from: http://ukr.segodnya.ua/politics/pnews/prezidenty-ukrainy-i-stran/Forsayt ekonomiky Ukrayiny: seredn'ostrokovyy (2015-2020 roky) i 
dovhostrokovyy (2020 - 2030 roky) chasovi horyzonty / nauk. kerivnyk proektu akad. NAN Ukrayiny M. Z. Z·hurovs'kyy / Mizhnarodna rada z nauky (ICSU) ta in. - K.: NTUU “KPI”, 2015, 136.

4. Innovatsiynyy universytet: kontseptsiya stanovlennya i rozvytku (2016) [Innovative University: the concept of formation and development]. monohrafiya / I.V. Art'omov, I.P. Studenyak, S.I.Ustych ta in., Uzhhorod, 524.

5. Vdovenko, YU. Ukrayina ta Yevropeys'kyy investytsiynyy fond Eberta. Ukrayins'ka pryzma. Spivpratsya Ukrayiny z mizhnarodnymy orhanizatsiyamy [Ukraine and Ebert European Investment Fund. Ukrainian prism. Cooperation of Ukraine with international organizations]. Retrieved from: http://www.fes.kiev.ua/new/wb/media/publikationen/prizma_ukr_int_2014.pdf. p. $16-25$

6. Ministerstvo ekonomichnoho rozvytku ta torhivli Ukrayiny [Ministry of Economic Development and Trade of Ukraine]. Retrieved from: www.me.gov.ua/

7. Ministerstvo zakordonnykh sprav Ukrayiny [Ministry of Foreign Affairs of Ukraine]. Retrieved from: www.mfa.gov.ua/ 